Comparative Philosophy Volume 3, No. 2 (2012): 47-55

Open Access / ISSN 2151-6014

www.comparativephilosophy.org

CONSTRUCTIVE ENGAGEMENT DIALOGUE (2.6)

\title{
REPLIES TO CORY, EL-BIZRI, MOU AND PESSIN
}

\section{MOHAMMAD AZADPUR}

It is a great pleasure to reply to the insightful remarks of my colleagues, who raise a number of very important and challenging issues, and I hope I can do justice to them and at the same time clarify some of the controversial aspects of my book. As some of the remarks are shared, I have taken the liberty of addressing them where I see fit and avoided a repetition of the replies.

\section{THERESE SCARPELLI CORY}

Through the intervention of Cory's comments, I hope to distance myself from some of the unsavory implications of my position. After all, I have nothing against the vetula in her quest to become deiform and achieve perfect union with God.

I should then begin with the appearance of elitism in my rendition Islamic Peripateticism. Cory writes:

Certainly the philosopher works hard to cultivate virtue, since that is the only way to gain the immortal "acquired intellect." But what about the little old lady who is equally assiduous in cultivating virtue? Through no fault of her own, according to the Islamic Peripatetic model, she is denied perfect union with God in this life, and loses the opportunity for immortality. [See 26-27 of the current issue. $]^{1}$

There is elitism, if the philosopher is committed to the view that people are, for the most part, essentially deprived of the capacity for salvation, and that salvation is dependent on this distinction in the essence of human beings. Now it may be that due to the difficulty in the process of attaining philosophical excellence, few people do actually attain it; but that to me is not elitism per se. There is a further issue, which is also pointed out by Cory, that philosophical cultivation presupposes a certain amount of leisure and education, which may not be available to everyone. In other words, are

\footnotetext{
${ }^{1}$ The page numbers of the critics' citation references in the current issue are given in bracket parentheses.
} 
philosophy and religion two different projects that channel salvation for two contingently different kinds of people, the elite and the commoner, respectively? Is that not a milder but no less problematic form of elitism?

Let me begin by saying that Islamic Peripatetics, as I understand them, by virtue of subscribing to the idea of religion as revealed to the philosopher-prophet-king, are not committed to a separation between religion and philosophy, in that way. The religious law and practices provide the starting point of a training that culminates in the perfection of the intellect, which is itself a spiritual faculty and of central importance for revealed religions. Without the preparation provided by the law and practices prescribed by religion, philosophical training proper cannot begin. Now in the Avicennan version of this view of religion, I maintain, the cultivation of imagination can itself culminate in a conjunction with the Active Intellect. This is possible, as I explain in more detail in my reply to Pessin, in virtue of the training of our feelings of pleasure and astonishment through the experience of the great work of art.

So the vetula, in this alternative view, will have to begin with submission to law and commitment to the practices prescribed by the revealed religion. Then she can engage in either the aesthetic training provided by the scriptural art or proceed with philosophical training. Either way, she has to dedicate herself to the project of selftransformation, and her success is the measure of her commitment to that process. I should also add that the philosophers and the poets-in-training are restless souls vying for the intensification of the intimacy that is available in varying degrees to the "faithful" in the various stages of initiation.

Cory also takes issue with my claim that Thomas Aquinas' interiorization of the Active Intellect is a source of the divide between religion and philosophy or faith and reason, a separation that characterizes much of subsequent philosophy. She asks: "I wonder, then, if Azadpur's objection is really directed, not at immanentized psychologies, but at abstractionist theories of cognition. In other words, perhaps the objection ought to run something like this: If intelligibles are cognized only by abstracting them from extramental sensible objects (rather than by receiving them directly from a separate Agent Intellect), then the human intellect seems to be restricted to this-worldly, empirical objects." [24] I am not sure that the abstractionist view can be problematized in this way, and Cory herself offers attractive responses to such a critique of abstractionism any way. In my view, the problem stems from the characterization of the spiritual as extra-intellectual and once you combine that with abstractionism, then all intelligibles are restricted to the material world and cognitive access to the spiritual realm is ruled out. I would add that this is probably not a charitable construal of Thomas's view, but one could probably find versions of it in of the work later (especially modern) philosophers who appropriate the faith and reason divide to which Thomas did contribute. Finally, the internalization of the Active Intellect obscures the incentive for moral and epistemic progress that I discuss in my reply to El-Bizri's critique of the Peripatetic notion of the Active Intellect. 


\section{NADER EL-BIZRI}

I remember reading El-Bizri's book, The Phenomenological Quest: Between Avicenna and Heidegger, with fondness as I was putting the final touches on my book. It certainly illuminated aspects of my project, but it was too late for me to respond to it in a very substantial way. So I was looking forward to El-Bizri's comments so as to discuss more extensively some of the issues regarding our engagements of similar figures and topics.

I believe that El-Bizri's critical remarks can be summed up by saying that I did not quite succeed in showing the modern relevance of Islamic Peripateticism. He says:

Having said that, one ought to indeed reflect on the phenomenon of the spiritual incapacitation of philosophy (108); albeit, this can be done by accentuating the primacy of ethics over ontology, over cosmology and epistemology, without retaining nostalgic poetizing imagery or reactionary relativistic commitments to Peripatetic or Neo-Platonist pictures that are no longer sustainable in our epoch. [33]

El-Bizri's lingering doubts about the relevance of the Peripatetic moves for modern thought are especially poignant as I repeatedly claim and argue that such moves are indeed relevant, if not necessary (in a prescriptive sense). So, perhaps I need to say some more about this.

El-Bizri finds something unique and positive in the way modernity is as an epoch and the vantage point shared by modern philosophers. For him, there is something at work in modernity (what El-Bizri calls "the age of modern technoscience," [29, 33, 34]) perhaps in the advances that science has made and technology has appropriated, that is fresh, novel, and revelatory. And the profound thinkers of the modern epoch, and surely Heidegger is among them, have done much to curtail premodernity's metaphysical (and poetic) excesses and have gone a long way toward establishing a demystified view of human beings and their world (while maintaining as much of the earlier tradition's relevant insights). For El-Bizri, the claim that ethics is "a prolegomenon to philosophical thinking" [31] is the only valuable contribution of my work to the study of Islamic Peripateticism.

A main task of Reason Unbound has been to offer a more general (than a mere ethical) anti-dote to modernism - the thesis that modernity involves a radical (and progressive) departure from the past and requires a new philosophy. Now short of reciting the arguments of the book all over again, I say that my dismantling of modernism begins with a serious consideration of the primacy of ethics. Such a starting point goes a long way in taking down a fundamental dualism definitive of modernism: the divide between mind and world. Ethical training involves the cultivation of a kind of sensitivity to the moral requirements embodied in particular circumstances, and once we are able to follow through this starting point, the notion of a purely causal world that is denuded of values and concepts begins to lose its grip 
on us. The purely causal world is the modernist's demystified world and its vanishing grip is a main outcome of the ethical preparation. There are at least two further related points that I make in my book: 1) The ethically initiated erosion of the mind-world dualism entails that the mind reaches all the way down, but not at the expense of exposing us to a supernatural Platonism ${ }^{2}$ or a mere "congruence of subjectivities." 3 Instead, the concepts, that is, the abilities to cognize intelligibles, are drawn in passively in our experience of the world and actively in our judgments about it. Knowledge, that is, our judgments getting things right, is preserved, while affirming our involvement in making "things" show themselves. 2) Freedom from the grip of problematic theses that preserve the mind-world dualism is not a merely intellectual matter. I believe this is a point that that chafes Ei-Bizri's modernist sensibility and compels him to call my work preparatory. [35] Of course, one is not going to whisk oneself away from the bewildering web of reflective and pre-reflective perplexities (including modernism) by simply reading a book; that is not how philosophy as a way of life works. My book, as an instrument in the repertoire of the transformative approach to philosophy, is designed to effect a disturbance (especially in one who is in the grip of the modernist sensibility); as such, Reason Unbound is indeed preparatory and may result in the practice of the philosophical cultivation necessary for genuine liberation and authenticity.

In the end, I would like to address El-Bizri's critique of the relevance of the Islamic Peripatetic notion of a separate Active Intelligence. He finds it a mythical remnant of a bygone age:

One can still evoke the significance of virtue-ethics and stress its primacy in preceding intellectual inquiry (104) or scientific research. This aim does not anymore require the continuation hitherto of conversations about an Active Intellect within our contemporary intellectual settings. It is not also a wellfounded critique to level against Heidegger that he was reductive in his approach by doing away with the notion of a separate intelligence, and by following the footsteps of his predecessors that went down the route of Thomism (pp. 105107). Heidegger's thought unfurled against the background of his preoccupation with the question of the meaning, truth, and place of being in a scientific age that is marked by the unfolding of the essence of modern technology. [33]

In my book, I devote a considerable effort to discussing the Peripatetic notion of a transcendent Active Intellect. The Active Intellect is the actualized intellect, that is, the intellect that has become all things and has the intelligibles within. The Peripatetic opponents of a transcendent Active Intellect assign its function to the human intellect.

\footnotetext{
2 In Mind and World, John McDowell refers to this position as "rampant Platonism" as the view that the mind apprehends a super-human meaning $(1994,77)$. This is the more general account of the same Platonism that he criticizes earlier (in the context of a metaethical discussion) as the consoling myth of rules as rails $(1981,149)$. This is not an outright rejection of Platonism, as McDowell also labels his own position as a kind of Platonism (1981, 156. See also 1994, 92).

3 This is Stanley Cavell's phrase as quoted by McDowell (1981, 149). I mean to emphasize the criticism offered by McDowell of Cavell's view as still in the grip of the mind-world dualism.
} 
But then it is difficult to explain how the same intellect can be actual and potential simultaneously. I recognize that the dispute about the transcendence of the Active Intellect is almost as old as Aristotelianism itself, and my aim is not to get bogged down in the dialectical exchanges between the proponents and the opponents of this notion. Instead, I argue that the proponents of a transcendent Active Intellect succeed better in reconciling faith and reason, philosophy and revealed religion. And of course, one problematic feature of modernism is its feebleness in negotiating a satisfactory resolution of these dualisms, and one of the factors contributing to this infirmity is the apparent unpalatability of a transcendent Active Intellect. For my Peripatetics, religious expressions are symbolic manifestations of what philosophical thought aims to uncover intellectually, and a transcendent Active Intellect, for these philosophers, is not a consolation from getting things right. It brings to view the difficulty of a transparent awareness, which is the elusive reward (vis-à-vis a conjunction with the Active Intellect) of the humble and virtuous knowledge seekers. Moreover, the invocation of the transcendent Active Intellect and the aspiration to conjoin with it are incentives for further ethical and epistemic progress. Latin antiAverroists found in this view a challenge to the authority of the church and sought to discredit it. Subsequently, even when the church's condemnation lost its grip on educational institutions, mainstream philosophy was not able to shake off the spiritually inert role assigned to it in medieval universities.

\section{Bo MoU}

Mou gets to the point right away by putting forth a familiar account of philosophical inquiry and contends that it is more general than the ones I put forth in my book. He has in mind my appropriation of the competing views of the philosophical inquiry that Pierre Hadot, in his now famous Philosophy as a Way Life, pits against one another. For Hadot, mainstream historians of philosophy, when they come to ancient philosophy, take it to be in the business of producing philosophical discourse. This he takes to be at odds with the project that the ancients themselves undertook and called philosophy. For them philosophy was primarily the practice of spiritual exercises aimed at the transformation of the self and the acquisition of wisdom. ${ }^{4}$ Now a central claim made in my book is that Hadot's reading of ancient philosophy is the conception of philosophy Muslims inherit from the Greeks. Mou, however, maintains that " $[\mathrm{m}]$ any think that the critique (taking nothing absolutely immune from criticism and without blindly claiming anything) and justification (understood in a broad way) constitute two closely-related (prescriptive) defining features of philosophical inquiries". [37] Given this broader conception of philosophical inquiry, Mou comments that "[a]ctually, both the production of the abstract rational theory account and the practice of spiritual exercises can go in distinct directions: either in the critical/justification direction or in the faith-based divinely direction." [37]

\footnotetext{
${ }^{4}$ Hadot 1995, 269.
} 
This is an interesting distinction, but I would like to suggest that it is itself an item in the modernist's repertoire. To be more precise, this distinction can be seen as a reformulation of the modernist contrast between faith and reason or religion and philosophy. In this light, I do have something to say about that account. Islamic Peripatetics did not see a fundamental difference between the purpose of religious practice and that of philosophy. For them, both aimed at the attainment of truth (haqīqa). In fact, they maintained that philosophy itself ought to belong to the core of religion's transformative technologies, and religious symbolism and practices ought to contribute to the initiation of the person into the philosophical way of life. Indeed, in this picture, religion is not in the business of articulating systems of dogma, which one believes blindly (has faith in). Rather, "faith," as Karen Armstrong has pointed out, is rather to "give yourself" or "commit yourself" to (or "engage") the way of life symbolized by the belief. In her essay, "Faith and Modernity," she writes that "the Latin word credo (translated now as "I believe") seems to have derived from the phrase cor dare: to give one's heart. The Middle English word beleven meant to love. When Christians proclaimed: credo in unum Deum, they were not so much affirming their belief in the existence of a single deity as committing their lives to God." ${ }^{5}$ I would add that in this approach, God is the real as such, and a commitment to God means the embracing of the way of truth, i.e., the practice of getting reality right. It is by the engagement in the purifying spiritual practices that we become like that which we seek to know, and it is only thus that we can know it. The dogmatic approach to faith, on the other hand, is on par with the approach to philosophy that aims at the mere production of rational discourse, they both miss the alchemical dimension of philosophy and religion, that is, the transformation of the self to the point of achieving intimacy with the divine.

Having said this, I would like to respond to another of Mou's questions. He asks, "given that Islamic Peripatetic tradition includes the prophecy discourse as its crucial portion, how can one look at the due relationship between the critique/justification character of philosophical activities and the imagination power of prophecy? Should such imagination be regulated by adequate critique/justification or eventually be based on religious faith in God (in the Islamic sense of the term)?" [38] Yes, prophecy and philosophy are different sides of the same coin, and the test of prophecy is in its philosophical coherence. Of course, we should understand by "philosophy" the practices of self-transformation for the sake of wisdom and by "prophecy" more than the foreshadowing of future events. In my book, I spend a lot of time working out the notion of prophecy as developed by Islamic Peripatetics. The lowest form of prophecy is the anticipation of future events, and at its apex, it is the direct grasp of the intelligibles. I should add that in the Peripatetic prophetic philosophy, the venues of divine mercy are not limited and wisdom and its relevant practices are available throughout history and across geographical boundaries. ${ }^{6}$ There are some Islamic traditions that claim a more direct path, but the Peripatetic paths to truth are as

\footnotetext{
${ }^{5}$ Armstrong 2004, 73.

${ }^{6}$ See my brief treatment of Hegel's philosophical chauvinism in Azadpur 2011, 73-4.
} 
multifarious as that allowed by the limits of human ingenuity and inspiration in the quest for the Good.

A third point raised by Mou concerns the non-Peripatetic forms of Islamic philosophy. He asks whether they all forms of Islamic philosophy by the conception of philosophy as a way of life. [39-40] I answer in the affirmative. Alternative forms of Islamic philosophy, like those more heavily Platonist, Plotinian, skeptical, etc., also operate within the framework of philosophy as a practice of spiritual exercises for the sake of virtue and wisdom. This is in agreement with what Seyyed Hossein Nasr writes, rather eloquently and concisely, as a way of characterizing all species of Islamic philosophy: "This conception of philosophy as dealing with the discovering of the truth concerning the nature of things and combining mental knowledge with the purification and perfection of one's being has lasted to this day wherever the tradition of Islamic philosophy has continued and is in fact embodied in the very being of the most eminent representatives of the Islamic philosophical tradition."7 Different schools of philosophy in the Islamic tradition realize this conception differently. In my book, for instance, I draw upon Abū Hāmid Muhammad al-Ghazzālī’s position to highlight a form of "Islamic philosophy" that stems from ancient skepticism and is critical of the Peripatetic approach.

\section{SARAH PESSIN}

I sympathize with Pessin's anxieties in trying to represent a philosophical tradition that is relegated to the margins of mainstream philosophy and holds a key to dissolving some of its most perplexing problems. My sympathy is multiplied by the historical connections and shared commitments of Medieval Islamic and Jewish thinkers. My excursion into Thomas' explicit disavowals of the views of Islamic thinkers stems from my attempt to diagnose a source of the misreadings that affects not only the Western reception of Islamic philosophy (and medieval Jewish philosophy, for that matter) but also the contours of the ensuing philosophical enterprise. I do not want to put the entire weight of such misreadings on Thomas; his critique of Avicenna's theory of the Active Intellect is not the only source; another salient wellspring of the aberrations in the subsequent tradition of Western philosophy is the rise of ethical voluntarism in late thirteenth century, and here Thomas' own views are themselves challenged and marginalized. ${ }^{8}$ These are just two of the more explicit sources of opposition to the tradition of Islamic Peripateticism. I do not deny that there are other more subtle (and perhaps more pernicious) ones, and I'd be happy to learn more from Pessin.

Pessin asks "why invoke Heidegger in this project at all?" [43] I understand her concerns about Heidegger. In a context, where "introducing" the Islamic Peripatetics is the order of the day, why should they be related to a philosopher whose atrocious conduct is well-documented and nothing short of appalling? Having said that, I

\footnotetext{
${ }^{7}$ Nasr 1996, 24-25.

${ }^{8}$ See Kent 1995, especially 40-6.
} 
should now emphasize that I engage Heidegger for three main reasons. First, I draw extensively on Henry Corbin's reading of Islamic Peripatetics, and Corbin's position is rooted in early Heidegger. Second, Early Heidegger is immersed in scholastic Aristotelianism and draws heavily from it in his phenomenology. His aim is to avoid the institutionalization of Aristotle-interpretation, and that comes at the cost of obscuring the Aristotelian origins of his view. Thirdly, Heidegger-interpretation is the site of a fascinating exchange between John McDowell and Hubert Dreyfus, where McDowell brings to light Dreyfus' commitment to a problematic view of the relation between mind and world. I especially wanted to seize that opportunity to point to some of the problematic aspects of the contemporary theories of mind, especially since I found those aspects insidiously at work in missing the point of the approach to philosophy as a practice of spiritual exercises. Having said that, I took every opportunity to point out the unsavory figure of Heidegger and the relation of his philosophy to his appalling choices.

Having responded to Pessin's initial worry, I want to turn to the core of her concerns about the various senses of "spiritual practice" in my work. She asks first "whether the initial training or the resulting phronesis is more properly illustrative of the 'spiritual practice' that he has in mind when he emphasizes that Islamic rationalism is itself deeply tied up with spiritual practice." [44] For me, spiritual practices are only instrumental. So the initial ethical training is obviously "spiritual practice" in the sense that I mean it. It aims at phronesis or practical wisdom. Now, phronesis, to put it in a nutshell, is the ability to recognize the good in a particular situation and to be able to respond to its requirements swiftly. As such, it is itself the beginning of the process that culminates in the acquired intellect, i.e., the intellect which grasps the secondary intelligibles (including but clearly going beyond the moral intelligibles - e.g., the good) immediately. So the practice of phronesis is at the service of a higher good, and a spiritual practice.

Pessin, then, wonders that if "the source of the ethical training is itself a divinely revealed Islamic Law, does that not put a kind of Divine Command Theory at the foundation - and does such a foundation not risk overshadowing the fluidity of Aristotelian phronesis with a more rigid mode of 'following God's law'?" [44] This is also a very important question. Islamic Peripatetics attribute the legislative act of the prophet-philosopher to his perfected imagination, and such an imagination enables him to provide a set of laws that are easy to understand and persuasive so that the initiate can begin the process of self-overcoming. The practices get intensified at the level of supererogatory ascetic exercises and result in the transparent awareness of the good that marks the stage of phronesis. The process goes even further as the theoretical intellect is cultivated. Therefore, the Divine Law, for the Islamic Peripatetics, is only the lowest rung of the practices that culminate in wisdom. Nevertheless, it is an essential part of the process of sapiential development.

In response to Pessin's questions about my contributions to the understanding of poetic interpretation ( $t a$ 'wi $)$, [45-6] I should begin by emphasizing that, with Avicenna, Islamic Peripateticism comes to acquire a further engagement of the faculty of imagination in the advanced stages of the philosophical development, i.e., 
beyond practical wisdom. The earlier engagement concerns the divine law. In the later forms of this engagement, the person may take on the symbolic aspect of sacred

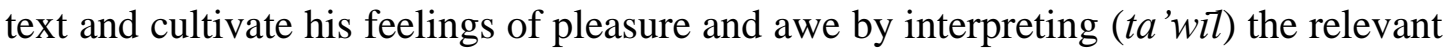
presentations of the Good in the text (work of art). As I argue in my book, in his Poetics, Avicenna contrasts this aesthetic refinement with the refinement of the theoretical intellect by the philosopher, and maintains that the former can also bring the person to the brinks of divine inspiration. ${ }^{9}$ This is the start of the obsession with the imaginal in the subsequent Islamic philosophers. Also this is where I place Corbin's concern with the symbolic rather than the allegorical approach to Avicenna's own efforts at poetic production. As Corbin rightly points out, drawing on a distinction indigenous to Romantic poetics, Avicenna's poetic treatises are not allegories, that is they are not publicly available representations of a point that is otherwise accessible more precisely and directly to the elite philosopher in his intellectual quest. Rather, the symbols are hierophanies, and their exegesis ( $t a$ 'wil) refines his inner life and enables him to become deiform (i.e., attain theosis or ta'alluh). ${ }^{10}$

\section{REFERENCES}

Armstrong, Karen (2004), "Faith and Modernity," in Betrayal of Tradition: Essays on the Spiritual Crisis of Modernity, ed. Harry Oldmeadow (Bloomington, Indiana: World Wisdom).

Azadpur, Mohammad (2011), Reason Unbound: On Spiritual Practice in Islamic Peripatetic Philosophy (Albany, NY: State University of New York Press).

Corbin, Henry (1960), Avicenna and the Visionary Recital, trans. Willard Trask (London: Routledge \& Kegan Paul).

El-Bizri, Nader (2000), The Phenomenological Quest: Between Avicenna and Heidegger (Binghamton, NY: Global Publications).

Hadot, Pierre (1995), "Philosophy as a Way of Life," in Philosophy as a Way of Life, trans. Michael Chase (Oxford: Blackwell).

Kent, Bonnie (1995), Virtues of the Will: The Transformation of Ethics in the Late Thirteenth Century (Washington, DC: Catholic University Press of America).

McDowell, John (1981), "Non-Cognitivism and Rule-Following," in Wittgenstein: to Follow a Rule, eds. Steven H. Holtzman and Christopher M. Leich (London: Routledge \& Kegan Paul).

McDowell, John (1994), Mind and World (Cambridge, MA: Harvard University Press).

Nasr, Seyyed Hossein (1996),"The Meaning and Concept of Philosophy in Islam," in History of Islamic Philosophy, Part I, eds. Seyyed Hossein Nasr and Oliver Leaman (London: Routledge).

${ }^{9}$ Azadpur 2011, 75-9.

${ }^{10}$ Corbin 1960, 28-34. 